\title{
Fruit thinning and its effect on yield and quality of apricot fruits "Priana"
}

\section{Taher A. Yehia' ${ }^{1}$ M.A. Abdel-Mohsen ${ }^{1}$, Atef M. Hussien ${ }^{2}$ and Hend H. K. Hussein ${ }^{2}$}

${ }^{1}$ Pomology Dept., Faculty of Agriculture, Cairo Univ., Giza, Egypt.

${ }^{2}$ Deciduous Fruit Tree Research Dept., Horticulture Research Institute, Agricultural Research Center, Giza, Egypt.

$$
\text { Received: } 04 \text { Sept. } 2019 \text { / Accepted } 14 \text { Oct. } 2019 \text { / Publication date: } 20 \text { Nov. } 2019
$$

\begin{abstract}
Priana apricot trees usually carry a very heavy crop of small fruit and reduction of quality. Fruit hand thinning is hard activity in a short period of time and a reliable good way to low crop level and enhance the fruit quality to be acceptable with the prices which exporting is too difficult to apricot fruits. Consequently, hand-thinning of Priana cv. fruits were applied on 5 years old trees for two times through fruit set or Pit hardening. In both times there were three intensity of thinning were done $40 \%$, $50 \%, 60 \%$ during two consecutive years 2016 and 2017. The results showed that to obtain high fruit quality with reasonable yield, the hand thinning at 40 or $50 \%$ procedure at the fruit set stage will work on it. However the $60 \%$ thinning will provide luxury fruits, especially in terms of size, but this will be achieved with high reduction in crop yield. While, control (without thinning) treatment for thinning was given despite a high yield, but the quality of the physical or chemical fruits was very low.
\end{abstract}

Keywords: Hand thinning, Apricot, Priana, Fruit characteristics.

\section{Introduction}

Apricot is one of the most economically important fruit crops belonging to the Prunus genus with an attractive, delicious, high vitamin and mineral content. Fruit was being cultivated in temperate climates of all the continents of the world (Bhat et al., 2013). Apricot production and consumption is still mainly restricted to the Mediterranean basin. Apricots are the third most produced stone fruit after plums and peaches (FAOSTAT. Available online: http://www.fao.org/faostat/en/\#data/QC, accessed on 2019). In 2017, harvested apricots area in Egypt was 14931 Feddn with production reached 96226 tons.

In Priana, under favourable conditions, as well as in other Apricot trees (Prunus armeniaca) and all stone fruits have produced high numbers of flowers when most of these flowers set; then trees have more fruits than they can carry until harvest crop. Branches of trees can break from the weight of a heavy crop. Also, crop load adjustment through fruit thinning is hence a commercial practice to obtain a competition for assimilates among fruits for nutritional substances and marketable product (Costa and Vizzotto, 2010; Rettke and Dahlenburg, 1999).

In addition, the apricot "Priana" is the new apricot cultivar recently introduced into Egypt, which is the French apricot (parent country) cultivar from parents ("Hamidi x Canino"). It's new early maturing cultivar (Audergon et al., 1991; De Vicente et al., 1998; Uzun et al., 2007 and Uzun et al., 2010) which has early flowering and high yielding cultivar (Alburquerque et al., 2004) with softest fruits (Pinar et al., 2010), most suitable to the market owing to its precocity (Polat and Caliskan 2010), and also can be grown in low-chilling requirement 150 - 250 hours (Küden et al., 1995; Bahar and Son, 2012). But as a result of its heaviest bearing, the fruits become small.

Most apricot growers worldwide remove manually the excess fruit to increase the fruit size normally (Webster and Spencer, 2000; Son, 2004). The thinning technological procedure was considered for many years as a one of the most important factor that regulates the production and controls fruit quality (Chira and Chira, 2014). Correct fruit thinning allows each fruit to receive more light which improves fruit color and flavor too. Fruit thinning also prevents the occurrence of some pest.

As a general, thinning will increase fruit size while also reducing total yield, and thus a balance between yield and fruit size must be achieved (Day et al., 1992). Larger fruit bring a higher market

Corresponding Author: Hend H. K. Hussein, Deciduous Fruit Tree Research Dept., Horticulture Research Institute, Agricultural Research Center, Giza, Egypt. E-mail: hendhh@hotmail.com 
price especially short fruiting life cycle. Thus, this research aimed to study the effects of hand fruit thinning on the quality of apricot cv. Priana fruits.

\section{Material and Methods}

The experiment was initiated to improve the fruit quality of "Priana" apricot by doing a hand thinning. The present study was carried out during the growing seasons 2016 and 2017 on 5 years old apricot trees, planted in a private farm at kilometer 84 from Cairo (Cairo Alexandria desert road). These trees were uniform as possible and planted 4 x 5 meters apart and grown in sandy loam soil and irrigated with drip irrigation from well (underground water). Trees received a normal fertilization program during the growing season. The treatments were applied on each of woody shoots and spurs during 2 weeks after full blooming at fruit set and during 5 - 6 weeks after full blooming at pit hardening the following fruitlets thinning treatments were applied as Control (without thinning), Hand thinning at $40 \%$ (light thinning), 50\% (moderate thinning) and 60\% (heavy thinning).

The research study included the effect of each thinning treatment on the following parameters:

Fruit physical parameters: The average fruit weight, and flesh weight $(\mathrm{g})$ of fruits were determined on a digital electric balance in fruit samples for each of the treatment. Also, average fruit length (L) and diameter (D) in $\mathrm{cm}$ was measured by using a vernier caliper, the fruit shape index was calculated as ratio of (L: D).

Fruit chemical analysis: Total soluble solids (TSS \%) of fruit juice were carried out by using hand refractormeter $\left(\right.$ Brix $\left.^{\circ}\right)$ according to A.O.A.C. (1990). While, Total titratable acidity percentage was determined in fruit juice as malic acid according to A.O.A.C. (1990) by titration with 0.1 sodium hydroxide and phenol phthalene as indicator. Then, total soluble solids/acid ratio was calculated as a ratio between T.S.S and acidity percentage.

Total yield: The produced fruit yield per tree was attained as average fruit weight in $\mathrm{kg} /$ tree.

Number of spurs per selected shoots: were recorded at September (The end of each growing season).

Carbohydrates: were expressed as g/100g dry weight (DW). Samples from the leaves were taken in March, June and September and dried to estimate carbohydrates. A known weight $(0.1 \mathrm{~g})$ of each sample was dried and placed in a test tube with HCL acid (10ml.). The tube was kept for 6 hours in an oven at $100^{\circ} \mathrm{C}$. The solution was filtered clarify by the leading and de-leading method using lead acetate solution $(137 \mathrm{~g} / \mathrm{L}$.) and the excess of lead salt was precipitated using N/3 potassium oxalate solution. The extract was measured into a measuring flask $(50 \mathrm{ml}$.) and completed with distilled water. Total sugars were determined according to the method of Dubois et al. (1956).

\section{Statistical analysis:}

The experimental design was randomized complete block design with 3 replicates trees for Priana cv. The obtained data in the two seasons were statistically analyzed using MSTAT package for analysis of variance (Snedecor and Cochran, 1989). Means were differentiated using Duncan multiple range test at significance level of 0.05 (Duncan, 1955).

\section{Results}

\section{Fruit physical parameters}

In general, the thinning process during the fruit set stage gave the highest significant increase in fruit and flesh weight compared to that during the hardening stage of both years. Also, the heavy thinning $(60 \%)$ achieved the highest significant increase in both seasons, while the control (without thinning) gave significantly less weight for fruit and flesh. furthermore thinning at $40 \%$ and $50 \%$ came in the middle with no significant difference between them (Table, 1). The interaction data show that fruit and flesh weight were at maximum level with $60 \%$ thinning treatment at fruit set in both seasons.

The same results presented in fruit length and diameter in (Table 2). The highest significant fruit characteristics were obtained in $60 \%$ thinning treatment at fruit set with significant differences between other treatments during the two seasons of each characteristic except concerning fruit shape 
Table 1: Effect of hand thinning degree and time on Fruit and Flesh weight of Priana apricot cultivar during 2016 -2017 seasons.

\begin{tabular}{|c|c|c|c|c|c|c|c|c|c|c|c|c|}
\hline Hand thinning degree & \multicolumn{5}{|c|}{$\begin{array}{l}\text { Fruit weight (g) } \\
\text { Thinning time }\end{array}$} & Mean & \multicolumn{2}{|c|}{ Fruit set } & $\begin{array}{l}\text { Flesh weight (g) } \\
\text { Thinning time }\end{array}$ & & Me & \\
\hline & & & & & & & & & & & & \\
\hline Control & 18.727 & ed & 18.727 & ed & 18.73 & $\mathrm{C}$ & 17.097 & $\mathrm{e}$ & 17.097 & e & 17.10 & $\mathrm{C}$ \\
\hline $50 \%$ & 29.587 & $\mathrm{~b}$ & 18.380 & e & 23.98 & B & 28.210 & b & 17.037 & $\mathrm{e}$ & 22.62 & B \\
\hline $60 \%$ & 36.230 & $\mathrm{a}$ & 19.353 & ed & 27.79 & A & 34.023 & $\mathrm{a}$ & 17.860 & de & 25.94 & A \\
\hline \multirow[t]{2}{*}{ Mean } & 27.860 & A & 19.070 & $\mathrm{~B}$ & & & 26.170 & A & 17.570 & $\mathrm{~B}$ & & \\
\hline & \multicolumn{12}{|c|}{$2^{\text {nd }}$ season } \\
\hline $40 \%$ & 26.493 & $\mathrm{c}$ & 19.497 & $d$ & 22.99 & B & 24.557 & $\mathrm{c}$ & 18.000 & $d$ & 21.28 & $\mathrm{~B}$ \\
\hline $50 \%$ & 29.970 & $\mathrm{~b}$ & 19.080 & $d$ & 24.52 & B & 27.680 & $\mathrm{~b}$ & 17.643 & $d$ & 22.67 & $\mathrm{~B}$ \\
\hline $60 \%$ & 35.950 & $\mathrm{a}$ & 18.987 & $\mathrm{~d}$ & 27.47 & $\mathrm{~A}$ & 33.953 & $\mathrm{a}$ & 17.517 & $d$ & 25.74 & A \\
\hline Mean & 27.960 & A & 19.240 & $\mathrm{~B}$ & & & 26.040 & A & 17.780 & $\mathrm{~B}$ & & \\
\hline
\end{tabular}

Table 2: Effect of hand thinning degree and time on fruit length, diameter, and shape index of Priana apricot cultivar during 2016 -2017 seasons.

\begin{tabular}{|c|c|c|c|c|c|c|c|c|c|c|c|c|c|c|c|c|c|c|}
\hline \multirow{5}{*}{$\begin{array}{c}\text { Hand thinning degree } \\
\text { Control }\end{array}$} & \multirow{2}{*}{\multicolumn{6}{|c|}{$\begin{array}{l}\text { Fruit length }(\mathrm{cm}) \\
\text { Thinning time }\end{array}$}} & \multirow{2}{*}{\multicolumn{6}{|c|}{$\begin{array}{c}\text { Fruit diameter }(\mathrm{cm}) \\
\text { Thinning time }\end{array}$}} & \multirow{2}{*}{\multicolumn{6}{|c|}{$\begin{array}{l}\text { Fruit shape index }(\mathrm{L} / \mathrm{D}) \\
\text { Thinning time }\end{array}$}} \\
\hline & & & & & & & & & & & & & & & & & & \\
\hline & \multicolumn{2}{|c|}{ Fruit set } & \multicolumn{2}{|c|}{ Pit hardening } & \multicolumn{2}{|c|}{ Mean } & \multicolumn{2}{|c|}{ Fruit set } & \multicolumn{2}{|c|}{$\begin{array}{l}\text { Thinning time } \\
\text { Pit hardening }\end{array}$} & \multicolumn{2}{|c|}{ Mean } & \multicolumn{2}{|c|}{ Fruit set } & \multicolumn{2}{|c|}{$\begin{array}{l}\text { Thinning time } \\
\text { Pit hardening }\end{array}$} & \multicolumn{2}{|c|}{ Mean } \\
\hline & & & & & & & & & & & & & & & & & & \\
\hline & 3.150 & de & 3.150 & de & 3.150 & $\mathrm{~B}$ & 3.183 & $\mathrm{f}$ & 3.183 & $\mathrm{f}$ & 3.183 & $\mathrm{C}$ & 0.9900 & $\mathrm{a}$ & 0.9900 & $\mathrm{a}$ & 0.9900 & $\mathrm{~A}$ \\
\hline $40 \%$ & 3.467 & $\mathrm{c}$ & 3.220 & $\mathrm{~d}$ & 3.343 & A & 3.733 & $\mathrm{c}$ & 3.397 & $\mathrm{~d}$ & 3.565 & $\mathrm{~B}$ & 0.9290 & $d$ & 0.9487 & $\mathrm{~b}$ & 0.9388 & B \\
\hline $50 \%$ & 3.623 & $\mathrm{~b}$ & 3.067 & $\mathrm{e}$ & 3.345 & A & 3.947 & $\mathrm{~b}$ & 3.260 & $\mathrm{e}$ & 3.603 & $\mathrm{~B}$ & 0.9180 & $\mathrm{e}$ & 0.9407 & $\mathrm{c}$ & 0.9293 & $\mathrm{C}$ \\
\hline $60 \%$ & 3.903 & $\mathrm{a}$ & 3.097 & $\mathrm{e}$ & 3.500 & $\mathrm{~A}$ & 4.120 & $\mathrm{a}$ & 3.363 & $\mathrm{~d}$ & 3.742 & A & 0.9473 & $\mathrm{~b}$ & 0.9207 & $\mathrm{e}$ & 0.9340 & $\mathrm{~B}$ \\
\hline \multirow[t]{2}{*}{ Mean } & 3.536 & A & 3.133 & $\mathrm{~B}$ & & & 3.746 & A & 3.301 & $\mathrm{~B}$ & & & 0.9461 & B & 0.9500 & A & & \\
\hline & \multicolumn{18}{|c|}{$2^{\text {nd }}$ season } \\
\hline $40 \%$ & 3.560 & $\mathrm{c}$ & 3.133 & $\mathrm{~d}$ & 3.347 & B & 3.753 & $\mathrm{c}$ & 3.367 & $\mathrm{e}$ & 3.560 & $\mathrm{C}$ & 0.9473 & $\mathrm{~b}$ & 0.9313 & $\mathrm{c}$ & 0.9393 & A \\
\hline $50 \%$ & 3.747 & $\mathrm{~b}$ & 3.090 & d & 3.418 & B & 3.887 & $\mathrm{~b}$ & 3.387 & de & 3.637 & B & 0.9643 & $\mathrm{a}$ & 0.91267 & $\mathrm{~d}$ & 0.9385 & A \\
\hline $60 \%$ & 3.873 & $\mathrm{a}$ & 3.143 & $\mathrm{~d}$ & 3.508 & A & 4.100 & $\mathrm{a}$ & 3.380 & de & 3.740 & A & 0.94467 & $\mathrm{~b}$ & 0.9310 & $\mathrm{c}$ & 0.9378 & A \\
\hline Mean & 3.577 & A & 3.124 & B & & & 3.792 & A & 3.390 & $\mathrm{~B}$ & & & 0.9424 & A & 0.9221 & B & & \\
\hline
\end{tabular}


(L/D ratio) revealed that the highest significant value was in control during the first season. In the second season, thinning treatment at $50 \%$ during fruit set was significantly achieved higher value than other treatments.

\section{Fruit chemical analysis}

\section{Total Soluble Solids (TSS)}

On general case, thinning degrees at fruit set showed higher significant differences in both seasons. Also the fruits of $60 \%$ thinning trees achieved the highest significant TSS while the fruits of the control treatment achieved significantly less TSS in both years of study (Table, 3). There were significant differences between $60 \%$ thinning degrees and all other treatments in the first season. However during the second season, $60 \%$ thinning treatment had the higher significant value except $50 \%$ thinning treatment.

\section{Acidity}

Data in Table (3) clears that, there were no significant differences on the effect of timing or severity of thinning on the acidity of the fruits during first season. In the second year, the acidity of the fruits was significantly higher with the process of thinning during the pit hardening stage compared to the procedure in the fruit set stage or with the treatment of control compared to thinning treatments. The lowest acidity obtained from $50 \%$ thinning treatment at fruit set $(1.807$ and $1.857 \%)$ during both seasons, respectively.

\section{TSS /Acid ratio}

Applied the fruit thinning process during the fruit set stage increased the ratio of soluble solids to acidity in both years compared to the doing it during pit hardening stage. Also, the severe thinning $(60 \%)$ led to an improvement in this percentage and without significant differences with $50 \%$ thinning in the first year and with 50 or $40 \%$ thinning in the second year (Table, 3). The results presented in TSS /acid ratio $50 \%$ thinning treatment at fruit set had higher significant value (7.713) than all other treatments except 40 and $60 \%$ thinning at fruit set and $60 \%$ thinning at pit hardening during the first season. Meanwhile, in the second season the highest significant value (7.207) was achieved by $60 \%$ thinning treatment at fruit set.

\section{Yield}

Generally, fruit yield decreased with increasing intensity of thinning and concerning to both thinning stages, yield at fruit set showed higher significant yield values than pit hardening in both seasons. According to Table (4) in both seasons, the highest significant yield was recorded by control (29.01 and $34.07 \mathrm{~kg} /$ tree). Also, 40\% thinning treatment in both seasons and 50\% thinning treatment in second season only all at fruit set had higher significant values than some of other treatments.

\section{Number of spurs}

It is clearly noticeable from Table (5) that doing thinning during fruit set stage resulted in a significant increase in the number of spurs per shoot in both seasons. Furthermore, $60 \%$ thinning degree at fruit set recorded the highest significant number of spurs (9.367 and 8.853) compared to other treatments in both seasons. While all hand thinning treatments which made during pit hardening stage gave the lowest values in compared to other thinning treatments made at fruit set. Also these results were significantly equal with the data achieved with control (without thinning).

\section{Carbohydrates}

The results in Table 6 clarify that during March, there was no significant effect, either to the degree or time of thinning on the content of carbohydrates during both seasons. While, in June and September, the fruit thinning during the hardening phase gave more carbohydrates in both seasons. In addition, during June, the control trees showed superiority in their carbohydrate content, especially in the trees where the fruit was thin during the fruit set in both seasons. On September, control gives the lowest significant difference average (10.36 and $12.95 \mathrm{~g} / 100 \mathrm{~g}$ DW) in both season respectively. While, the interactions results showed no significant differences obtained between 
Table 3: Effect of hand thinning degree and time on Total soluble solids (TSS), acidity percentage and TSS /acid ratio of Priana apricot cultivar during 2016 2017 seasons.

\begin{tabular}{|c|c|c|c|c|c|c|c|c|c|c|c|c|c|c|c|c|c|c|}
\hline \multirow{3}{*}{$\begin{array}{c}\text { Hand thinning } \\
\text { degree }\end{array}$} & \multicolumn{6}{|c|}{$\begin{array}{c}\text { TSS } \\
\text { Thinning time }\end{array}$} & \multicolumn{6}{|c|}{$\begin{array}{c}\text { Acidity \% } \\
\text { Thinning time }\end{array}$} & \multicolumn{6}{|c|}{$\begin{array}{l}\text { TSS /Acid ratio } \\
\text { Thinning time }\end{array}$} \\
\hline & \multicolumn{2}{|c|}{ Fruit set } & \multicolumn{2}{|c|}{ Pit hardening } & \multicolumn{2}{|c|}{ Mean } & \multirow{2}{*}{\multicolumn{2}{|c|}{ Fruit set }} & \multirow{2}{*}{\multicolumn{2}{|c|}{$\begin{array}{c}\text { Pit } \\
\text { hardening } \\
\mathbf{1}^{\text {st }} \text { season }\end{array}$}} & \multicolumn{2}{|c|}{ Mean } & \multicolumn{2}{|c|}{ Fruit set } & \multicolumn{2}{|c|}{$\begin{array}{c}\text { Pit } \\
\text { hardening }\end{array}$} & \multicolumn{2}{|c|}{ Mean } \\
\hline & & & & & & & & & & & & & & & & & & \\
\hline Control & 11.43 & $\mathrm{~b}$ & 11.43 & $\mathrm{~b}$ & 11.433 & $\mathrm{C}$ & 2.123 & $\mathrm{a}$ & 2.123 & a & 2.123 & A & 5.43 & $\mathrm{~b}$ & 5.430 & $\mathrm{~b}$ & 5.431 & $\mathrm{C}$ \\
\hline $40 \%$ & 13.78 & $\mathrm{a}$ & 11.45 & $\mathrm{~b}$ & 12.61 & $\mathrm{~B}$ & 1.900 & $a b$ & 1.943 & $a b$ & 1.922 & A & 7.263 & $\mathrm{a}$ & 5.927 & $\mathrm{~b}$ & 6.595 & $\mathrm{~B}$ \\
\hline $50 \%$ & 13.85 & $\mathrm{a}$ & 11.51 & $\mathrm{~b}$ & 12.68 & $\mathrm{~B}$ & 1.807 & $\mathrm{~b}$ & 1.957 & $a b$ & 1.882 & A & 7.713 & $\mathrm{a}$ & 5.890 & $\mathrm{~b}$ & 6.802 & $\mathrm{AB}$ \\
\hline $60 \%$ & 13.91 & $\mathrm{a}$ & 13.59 & $\mathrm{a}$ & 13.75 & $\mathrm{~A}$ & 1.840 & $\mathrm{~b}$ & 1.897 & $a b$ & 1.868 & A & 7.567 & $\mathrm{a}$ & 7.170 & $\mathrm{a}$ & 7.386 & $\mathrm{~A}$ \\
\hline Mean & 13.24 & A & 12.00 & B & & & 1.918 & A & 1.980 & A & & & 6.993 & A & 6.105 & B & & \\
\hline Control & 11.667 & $\mathrm{c}$ & 11.667 & $\mathrm{c}$ & 11.667 & B & 2.043 & $\mathrm{a}$ & 2.043 & $\mathrm{a}$ & 2.043 & A & 5.717 & $\mathrm{~d}$ & 5.717 & $\mathrm{~d}$ & 5.717 & $\mathrm{~B}$ \\
\hline $40 \%$ & 12.200 & $\mathrm{bc}$ & 11.667 & $\mathrm{c}$ & 11.93 & B & 1.877 & $\mathrm{~b}$ & 1.977 & $a b$ & 1.927 & B & 6.503 & $\mathrm{c}$ & 5.920 & $\mathrm{~d}$ & 6.212 & $\mathrm{AB}$ \\
\hline $50 \%$ & 12.700 & $\mathrm{ab}$ & 11.803 & $\mathrm{c}$ & 12.25 & $\mathrm{AB}$ & 1.857 & $\mathrm{~b}$ & 1.977 & $a b$ & 1.917 & B & 6.847 & $\mathrm{~b}$ & 5.990 & $\mathrm{~d}$ & 6.418 & $\mathrm{AB}$ \\
\hline $60 \%$ & 13.413 & $\mathrm{a}$ & 12.833 & $a b$ & 13.12 & A & 1.863 & $\mathrm{~b}$ & 1.920 & $a b$ & 1.892 & B & 7.207 & $\mathrm{a}$ & 6.690 & $\mathrm{bc}$ & 6.948 & A \\
\hline Mean & 12.490 & A & 11.990 & B & & & 1.910 & B & 1.979 & A & & & 6.568 & A & 6.079 & B & & \\
\hline
\end{tabular}

Table 4: Effect of hand thinning degree and time on yield (Kg/tree) of Priana apricot cultivar during $2016-2017$.

\begin{tabular}{|c|c|c|c|c|c|c|c|c|c|c|c|c|}
\hline Hand thinning degree & \multicolumn{2}{|c|}{ Fruit set } & $\begin{array}{c}1^{\text {st }} \\
\text { Thinn } \\
\text { Pit ha }\end{array}$ & & \multicolumn{2}{|c|}{ Mean } & \multicolumn{2}{|c|}{ Fruit set } & \multicolumn{2}{|c|}{$\begin{array}{l}\text { Thinning time } \\
\text { Pit hardening }\end{array}$} & & \\
\hline Control & 29.01 & $\mathrm{a}$ & 29.01 & $\mathrm{a}$ & 29.01 & A & 34.07 & $\mathrm{a}$ & 34.07 & $\mathrm{a}$ & 34.07 & A \\
\hline $40 \%$ & 24.78 & $a b$ & 20.43 & bc & 22.61 & $\mathrm{~B}$ & 32.72 & $\mathrm{a}$ & 26.10 & $\mathrm{~cd}$ & 29.41 & $\mathrm{~B}$ \\
\hline $60 \%$ & 21.67 & bc & 18.51 & $\mathrm{c}$ & 20.09 & $\mathrm{C}$ & 29.04 & $\mathrm{bc}$ & 23.15 & $d$ & 26.10 & $\mathrm{C}$ \\
\hline Mean & 24.59 & A & 21.99 & B & & & 31.59 & A & 26.93 & B & & \\
\hline
\end{tabular}

*Means with the same letter(s) at each row, column and interaction are not significantly different at $5 \%$ level of Duncan's multiple range tests. 
Table 5: Effect of hand thinning degree and time on number of spurs per shoot of Priana apricot cultivar during 2016 - 2017.

\begin{tabular}{|c|c|c|c|c|c|c|c|c|c|c|c|c|}
\hline \multirow{2}{*}{$\begin{array}{c}\text { Hand thinning degree } \\
\text { Control }\end{array}$} & \multicolumn{2}{|c|}{ At Fruit Set } & \multicolumn{2}{|c|}{$\begin{array}{l}\text { Thinning time } \\
\text { At Pit hardening }\end{array}$} & \multicolumn{2}{|c|}{ Mean } & \multicolumn{2}{|c|}{ At Fruit Set } & \multicolumn{2}{|c|}{$\begin{array}{l}\text { Thinning time } \\
\text { At Pit hardening }\end{array}$} & \multirow{2}{*}{$\frac{\text { Mean }}{3.790}$} & \\
\hline & 4.577 & $\mathrm{c}$ & 4.577 & $\mathrm{c}$ & 4.577 & $\mathrm{C}$ & 3.790 & $\mathrm{c}$ & 3.790 & $\mathrm{c}$ & & $\mathrm{C}$ \\
\hline $40 \%$ & 7.283 & $\mathrm{~b}$ & 4.310 & $\mathrm{c}$ & 5.797 & B & 5.923 & $\mathrm{~b}$ & 4.297 & $\mathrm{c}$ & 5.110 & B \\
\hline $50 \%$ & 7.900 & $\mathrm{~b}$ & 4.147 & $\mathrm{c}$ & 6.023 & $\mathrm{AB}$ & 6.280 & $\mathrm{~b}$ & 4.133 & $\mathrm{c}$ & 5.207 & B \\
\hline $60 \%$ & 9.367 & $\mathrm{a}$ & 4.143 & $\mathrm{c}$ & 6.755 & A & 8.853 & $\mathrm{a}$ & 4.157 & $\mathrm{c}$ & 6.505 & A \\
\hline Mean & 7.282 & A & 4.294 & B & & & 6.212 & A & 4.094 & $\mathrm{~B}$ & & \\
\hline
\end{tabular}

*Means with the same letter(s) at each row, column and interaction are not significantly different at $5 \%$ level of Duncan's multiple range tests.

Table 6: Effect of hand thinning degree and time on carbohydrates (g/100g dry weight) of Priana apricot cultivar during 2016 - 2017.

\begin{tabular}{|c|c|c|c|c|c|c|c|c|c|c|c|c|c|c|c|c|c|c|}
\hline \multirow{2}{*}{$\begin{array}{c}\text { Hand } \\
\text { thinning } \\
\text { degree } \\
\end{array}$} & \multirow{2}{*}{\multicolumn{2}{|c|}{ Fruit Set }} & \multirow{2}{*}{\multicolumn{2}{|c|}{$\begin{array}{c}\text { March } \\
\text { Thinning time } \\
\text { Pit hardening }\end{array}$}} & \multirow{2}{*}{\multicolumn{2}{|c|}{ Mean }} & \multirow{2}{*}{\multicolumn{2}{|c|}{ Fruit Set }} & \multirow{2}{*}{\multicolumn{2}{|c|}{$\begin{array}{c}\text { June } \\
\text { Thinning time } \\
\text { Pit hardening }\end{array}$}} & \multirow{2}{*}{\multicolumn{2}{|c|}{ Mean }} & \multirow{2}{*}{\multicolumn{2}{|c|}{ Fruit Set }} & \multicolumn{2}{|c|}{$\begin{array}{c}\text { September } \\
\text { Thinning time }\end{array}$} & \multirow{2}{*}{\multicolumn{2}{|c|}{ Mean }} \\
\hline & & & & & & & & & & & & & & & Pit hat & ning & & \\
\hline Control & 32.98 & $a b$ & 32.98 & $a b c$ & 32.98 & $\mathrm{AB}$ & 40.64 & $\mathrm{a}$ & 40.64 & $\mathrm{a}$ & 40.64 & A & 10.36 & $\mathrm{~b}$ & 10.36 & $\mathrm{~b}$ & 10.36 & B \\
\hline $40 \%$ & 32.59 & $a b c$ & 30.29 & $\mathrm{c}$ & 31.44 & $\mathrm{C}$ & 34.20 & $\mathrm{~b}$ & 38.27 & $a b$ & 36.24 & B & 11.30 & $a b$ & 13.5 & $a b$ & 12.40 & A \\
\hline $50 \%$ & 33.15 & $a b c$ & 34.38 & $\mathrm{a}$ & 33.76 & A & 34.26 & $\mathrm{~b}$ & 38.94 & $\mathrm{a}$ & 36.60 & B & 12.14 & $a b$ & 13.73 & $\mathrm{a}$ & 12.94 & A \\
\hline $60 \%$ & 30.97 & bc & 34.02 & $a b$ & 32.49 & B & 34.28 & $\mathrm{~b}$ & 38.61 & $\mathrm{a}$ & 36.45 & B & 11.81 & $a b$ & 13.73 & $\mathrm{a}$ & 12.77 & A \\
\hline Mean & 32.42 & A & 32.92 & A & & & 35.85 & B & 39.11 & A & & & 11.40 & B & 12.83 & A & & \\
\hline & & & & & & & & & $2^{\text {nd }} \mathrm{se}$ & & & & & & & & & \\
\hline Control & 34.13 & $\mathrm{a}$ & 34.13 & $\mathrm{a}$ & 34.13 & A & 41.12 & $\mathrm{a}$ & 41.12 & $\mathrm{a}$ & 41.12 & A & 12.94 & $\mathrm{c}$ & 12.94 & $\mathrm{c}$ & 12.95 & A \\
\hline $40 \%$ & 34.13 & $\mathrm{a}$ & 33.48 & $\mathrm{a}$ & 33.81 & A & 35.22 & b & 38.75 & $\mathrm{a}$ & 36.99 & B & 13.80 & $\mathrm{bc}$ & 14.80 & $a b$ & 14.30 & A \\
\hline $50 \%$ & 34.23 & $\mathrm{a}$ & 34.23 & $\mathrm{a}$ & 34.23 & A & 34.96 & b & 39.15 & $\mathrm{a}$ & 37.05 & B & 14.24 & $a b$ & 15.29 & $\mathrm{a}$ & 14.77 & A \\
\hline $60 \%$ & 34.37 & $\mathrm{a}$ & 34.30 & $\mathrm{a}$ & 34.33 & A & 35.15 & $\mathrm{~b}$ & 39.395 & $\mathrm{a}$ & 37.28 & B & 14.65 & $a b$ & 15.31 & $\mathrm{a}$ & 14.98 & A \\
\hline Mean & 34.22 & A & 34.03 & A & & & 36.61 & B & 39.60 & A & & & 13.91 & B & 14.59 & A & & \\
\hline
\end{tabular}

*Means with the same letter(s) at each row, column and interaction are not significantly different at $5 \%$ level of Duncan's multiple range tests. 


\section{Discussion}

For balanced fruit production, intensity and fruit load must be well adapted (Bussi et al., 2005). Whereas distance between fruits and thinning time has been reported to have positive effect on fruit size and quality (Drogoudi et al., 2009), however its response is closely related to thinning intensity, cultivar and tree size (Jimenez and Royo Diaz, 2002) and fruit thinning improved the fruit size (Chanana et al., 1998). Furthermore thinning was most effective in increasing the size of the remaining fruit when performed at or soon after initial fruit set. Number of fruit retained and tree yield were a direct reflection of thinning severity, whereas tree revenue was strongly influenced by fruit size (Oosthuyse and Jacobs, 1996). In this study, the improvement in the physical and chemical characteristics of the fruits, this was associated with early thinning in the fruit set stage compared to the late thinning in the pit hardening stage, or with the fruit thinning treatment compared to nonthinning confirms what was stated by many scientists. Whereas, early removal (blossom thinning) is currently used in many apple producing areas to reduced competition for photosynthates. Leaf area per fruit affects the number of spurs flowering the following season (Racskó, 2006). Also, the results in agreement with those of Rettke and Dahlenburg (1999) reported that all thinning treatments reduced the yield of fresh fruit. Total soluble solids level of the fruit was increased by thinning. Compared to the un-thinned, all thinning treatments increased the size of fresh fruit. Mean fruit weight and diameter progressively decreased as thinning was delayed from full bloom till stone pit hardening. The same findings also mentioned by Taghipour et al. (2011). Thinning by hand to improve fruit quality of 'Gerdi' apricot showed that hand thinning significantly increased fruit weight, volume and quality and from this aspect. Also, TSS and total soluble solids to total acidity ratio (TSS/ TA), pit weight and flesh to pit ratio characteristics were improved by hand thinning. Also, hand blossom thinning at $10 \mathrm{~cm}$ had the superior effect for it gave the lowest fruit weight, size, height, diameter, $\mathrm{SSC}$, titratable acidity and SSC/acid ratio compared to other treatments in Florida prince (El-Boray et al., 2012).

Furthermore, at thinning up to $25 \%$, seems to be the right thinning of apricot cv. Trevett because the increase in fruit weight with $40 \%$ thinning was 1.67 fold higher than control and the fruit yield per branch decreased with increasing intensity, and it was significantly less when thinning intensity was beyond $25 \%$. The TSS continued to increase significantly with increased thinning intensity. Highest total soluble solid (16\%) was recorded with 40\% thinning (Rab et al., 2012). As for Plum trees cultivars 'President' and 'Valor', hand thinning decreased cumulative yield of 'President' cultivar, also, did significantly diminish percentage of fruit set and increased their mean fruit weight in 'President' cultivar. 'Valor' responded with similar increase in mean fruit weight only after thinning introduced in later term, and did not significantly affect the soluble solids (Sosna, 2012).

The results of the carbohydrate estimation, which showed no significant differences during March, may be due to the fact that until March was not the thinning were not conducted where the first date of the thinning was at the stage of the fruit set. The results achieved by Nartvaranant (2016) who reported that a significant difference in citrus leaf carbohydrate content was found in 3-6 month after fruit set. At 3 months after fruit set, fruit thinning at 50\% gave significantly higher carbohydrate concentration than no thinning, whereas, after 6 month from fruit set, $50 \%$ fruit thinning gave significantly higher leaf carbohydrate than no thinning.

In general, the reduction of the initial crop load favored the accumulation of starch in leaves and soluble sugars in leaves and fruits (Haouari et al., 2013). Therefore, during June, the results of the superiority of the control tree in the content of carbohydrate compared to the coefficients of thinning may be result of the direction of the earlier thinning trees during fruit set to use the carbohydrates available in the formation of large fruit spurs, which is shown in Table 5. Whereas, Haouari et al., (2013) noticed that the reduction in initial fruit load had a positive significantly effect on the current year's shoot elongation.

In conclusion, although thinning is not given higher yields, but with the poor qualities of physical and chemical parameters of fruits. Therefore, to obtain high-quality fruits in Priana apricot cultivar, the process of early thinning in the stage of the fruit set may be an optimal solution. 


\section{References}

A.O.A.C. 1990. Association of official of analytical chemists, official methods of analysis. $11^{\mathrm{TM}}$ Ed.Published by the A.O.A.C. Washington, D.C., U.S.A., pp.915, 918, 1048 and 1058.

Alburquerque, N., L. Burgos, and J. Egea, 2004. Influence of flower bud density, flower bud drop and fruit set on apricot productivity. Scientia Horticulturae 102,397-406.

Audergon, J.M., M. Reich, and M. Souty, 1991. Abricot: variations des critères de qualité. Arboriculture fruitière 436: 35-45.

Bahar, A. and L. Son, 2012. Chilling duration of Silifke-Mersin region and its affects on fruit growing. Afr. J. Agric. Res. 7(49):6562-6564.

Bhat, M.Y., B.A. Padder, I.A. Wani, F.A. Banday, H. Ahsan, M.A. Dar, and A.A. Lone, 2013. Evaluation of apricot cultivars based on physico-chemical characteristics observed under temperate conditions. International Journal of Agricultural Sciences 3(5):534-537.

Bussi, C., F. Lescourret, M. Genard, and R. Habib, 2005. Pruning intensity and fruit load influence vegetative and fruit growth in an early maturing peach tree cv. Alexandra. Fruits, 60:133-142.

Chanana, Y.R., B. Kaur, G.S. Kaundal, and S. Singh, 1998. Effect of flowers and fruit thinning on maturity, yield and quality in peach (Prunus persica Batsch.. Indian J. Hort. 55: 323-26.

Chira, A. and L. Chira, 2014. Studies Regarding the Influence of Thinning on the Quality and Economic Efficiency of Some Apricot Fruit Varieties Bulletin UASVM Horticulture 71(1):122-123. Print ISSN 1843-5254, Electronic ISSN 1843-5394.

Costa G. and G. Vizzotto, 2010. Flower and fruit thinning of peaches and other Prunus. Horticultural Reviews: $351-387$.

Day, K.R.; R.S. Johnson, T.M. DeJong, and C.H. Crisosto, 1992. Comparison of high density training systems and summer pruning techniques and timing. Research Reports for California Peaches and Nectarines, California Tree Fruit Agreement. Sacramento, California, USA. 4pp.

De-Vicente, M.C.; M.J. Truco, J. Egea, L. Burgos, and P. Arus, 1998. RFLP variability in apricot (Prunus armeniaca L.. Plant Breeding 117(2):153-158.

Drogoudi, P.D.; C.G. Tsipouridis, and G. Pantelidis, 2009. Effect of crop load and time of thinning on the incidence of split pit, fruit yield, fruit quality and leaf mineral content in Andross peach. J. Hort. Sci. Biotech. 84: 505-09.

Dubois, M., F.Smith, K.A. Gilles, J.K. Hammiltion, and P.A. Robers, 1956. Colorimetric method to determination of sugars and related substances. Annal. Chem. 28 (3): $350-356$.

Duncan, D.B., 1955. Multiple range and multiple test. Biometrics, 11: 1-24.

El-Boray, M.S.; A.M. Shalan, and Z.M. Khouri, 2012. Effect of different thinning techniques on Fruit set Leaf area Yield and Fruit Quality parameters of Prunus persica, L. batsch cv. Floridaprince. Trends Hortic. Res., 1-13.

Haouari, A. M.C.Labeke, K. Steppe, F. Ben Mariem, M. Braham, and M. Chaieb, 2013. Fruit thinning affects photosynthetic activity, carbohydrate levels, and shoot and fruit development of olive trees grown under semiarid conditions. Functional Plant Biology, 40(11), 1179-1186.

Jimenez, C.M. and J.B. Royo Diaz, 2002. Fruit distribution and early thinning intensity influence fruit quality and productivity of peach and nectarine tree. J. American Soc. Hort. Sci. 127: 892900.

Küden, A.B.; N. Kaska, and S. Paydas, 1995. Determining the chill units of Adana and chilling requirements of apricots. Acta Horticulturae; (384):309-313.

Nartvaranant, P., 2016. Effects of fruit thinning on fruit drop, leaf carbohydrates concentration, fruit carbohydrates concentration, leaf nutrient concentration and fruit quality in Pummelo cultivar Thong Dee. Songklanakarin Journal of Science and Technology 38(3):249-255

Oosthuyse, S.A. and G. Jacobs 1996. Effect of time and severity of fruit thinning on fruit retention, fruit size, yield, and revenue in 'Sensation' mango. ISHS Acta Horticulturae 455: V International Mango Symposium.

Pınar, H., M. Bircan, C. Yılmaz, A. Yıldız, S. Paydaş Kargi, N. Kaşka, A. Yıldız, and L. Son, 2010. The Performance of some Apricot Cultivars in The Mersin Ecological Conditions. Acta Hort., 862,109-112.

Polat, A.A. and O. Caliskan, 2010. Determination of Growth and Fruit Quality Parameters of Some Apricot Cultivars in Subtropical Climate Conditions of Turkish Mediterranean Region. Acta 
Hort. 862:323-330

Racskó, J. 2006. Crop Load, Fruit thinning and their effects on fruit quality of apple (Malus domestica Borkh.. - Journal of Agricultural Sciences.

Rab, A.; J. Rahman, S. Abdiani, A. Qadim, M. K. Khattak, and K. Nawab, 2012. Thinning Intensity Affects The Yield and Fruit Quality of Apricot cv. Trevett. Pak. J. Bot., 44(3): 887-890.

Rettke, M.A. and A.P. Dahlenburg, 1999. Effect of timing of hand thinning on productivity of Moorpark apricots destined for drying. Australian Journal of Experimental Agriculture 39(7):885-889.

Son, L., 2004. Effects of hand and chemical thinning on fruit size and quality of 'Priana' apricot (Prunus armeniaca) cultivars. New Zeland Journal of crop and Horticultural science (3):331335.

Sosna, I., 2012. Effect of hand and chemical thinning on yielding and fruit quality of two late ripening plum cultivars. Acta Sci. Pol., Hortorum Cultus, 11(2):41-51.

Snedecor, G.W., and W.G. Cochran, 1989. Statistical Methods. 6th ed. The Iowa State Univ., Press, Iowa, U.S.A.p.593.

Taghipour, L., M. Rahemi and P. Assar 2011.Thinning with NAA, NAD, ethephon, urea and by hand to improve fruit quality of 'Gerdi' apricot. Braz. J. Plant Physiol., 23(4):279-284.

Uzun, A.; O. Gulsen, Y. Aka-Kacar, V. Aras, A. Demirel, M. Bircan, S. Paydas and A. Yildiz, 2007. Characterization of new apricot cultivars by RAPD markers. Journal of Applied Horticulture, 9(2):132-135.

Uzun, A., O. Gulsen, U. Seday, M. Bircan, and K.U. Yilmaz, 2010. SRAP based genetic analysis of some apricot cultivars. Romanian Biotechnological Letters, 15(4):5396-5404.

Webster, A.D. and J.E. Spencer, 2000. Fruit thinning plums and apricots. Plant Growth Regulation. (31):101-112. 